\title{
The Impact of Poverty, Unemployment, Inequality, Corruption and Poor Governance on Niger Delta Militancy, Boko Haram Terrorism and Fulani Herdsmen Attacks in Nigeria
}

\author{
"Olaniyi Evans ${ }^{1}$ \\ Ikechukwu Kelikume ${ }^{2}$

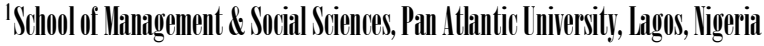 \\ 'Lagoos Business School,Pinl Ltlintic Iniversity, Liagos, ligeriil

\begin{abstract}
The purpose of this study was to examine the impact of poverty, unemployment, inequality, corruption and poor governance on Niger Delta militancy, Boko Haram terrorism and Fulani herdsmen attacks in Nigeria. Using annual data over the period 1980-2017, this study applied fully modified OLS (FMOLS) method of estimation. The outcomes of the estimations showed that poverty, unemployment, inequality, corruption and poor governance were significant causes of Niger Delta militancy, Boko Haram terrorism and Fulani herdsmen attacks in Nigeria. In line with theories of deprivation, the study found that the various deprivations in the country led to violence and conflicts in the form of Niger Delta militancy, Boko Haram terrorism and Fulani herdsmen attacks. Thus, violence was a result of the prevailing unpleasant socio-material conditions pertaining to survival, economic deprivation, structural inequities, environmental degradation and governance deficits.

Keywords: Poverty, unemployment, inequality, corruption, poor governance, Niger Delta militancy, Boko Haram terrorism, Fulani herdsmen attacks

JEL:D60, E27, H54, I31
\end{abstract}

Violent conflicts are largely responsible for the backwardness of nations. They hinder active participation in the social, economic and political progress of the country. The effects are evident on schools, churches, mosques and displacements of people. Obviously, the effects of this phenomenon in Nigeria are seen in the losses as a result of militants, terrorists and herdsmen attacks, which are major setbacks for development (Evans and Kelikume, 2018). The first incident of violence in Nigeria is the slave trade which degraded and deformed human dignity on a large scale. Nigeria was a victim of this inhuman trade as introduced and championed by the West. After the abolition of the slave trade, Nigeria has been a victim of many other incidents of violence ranging from imperialism (with its offshoot - colonialism), neocolonialism, coup d'état of 1966 (organized by some Nigerian majors), corruption galore, armed robbery (in the homes, streets, markets, and highways), religious crisis, and communal or regional crises (Ideyi, 2008).

The latest in the list of violence in Nigeria are the Niger Delta militancy, the Boko Haram terrorism and Fulani herdsmen attacks. The Niger Delta militancy arose in 2004 over tensions between foreign 


\section{Evans \& Kelikume}

oil corporations and the Niger Delta's minority ethnic groups who felt exploited and marginalized, particularly the ljaw and the Ogoni. There was ethnic and political unrest over competition for oil wealth between ethnic groups, causing the militarization of the entire region by ethnic militia groups, Nigerian military and police forces. Over time, the struggle deteriorated to criminal opportunism driven by the imperatives of economic profiteering. The violence also hit the oil industry with kidnappings and piracy. Notwithstanding the presidential amnesty program (which includes support and training of exmilitants), the organic dynamics of militancy in the Niger Delta have variously manifested in the fashion of oil pipeline vandalism, oil theft/bunkering, piracy, and kidnapping (Evans and Kelikume, 2018; Okoli and Nachanaa, 2016). Ikelegbe (2006, p. 87) described militancy in the Niger Delta thus:

"The resource agitations and conflicts in the oil rich Niger Delta region of Nigeria that were originally civil and communal have since been transformed into armed struggles conducted by disparate youth militia groups. Crime, violence and insecurity, state militarization, ethnic militia-ization and communal and ethnic wars now pervade the region. The consequences of militancy and militia-ization have been very disruptive and devastative to the economy, governance, inter-group relations, communal cohesion and security of the Niger Delta region".

Also, Boko Haram terrorism, one of the world's deadliest terrorist organization, has killed thousands of people over the past decade (see Figure 1). For example, in 2011, it blew up part of the United Nations offices in Abuja and in April 2014, it kidnapped 276 Chibok school girls. Boko Haram has struck in Niger, Chad, and Cameroon, but is mainly based in Nigeria where it executes asymmetrical bombings and attacks across the northern half of the country (Hendrix, 2016). There are 2.3 million Internally Displaced Persons (IDPs) and tens of thousands more in refugees fleeing from Boko Haram. The conflict has produced the world's biggest camp of displaced persons. Maiduguri has more than two million IDPs, overwhelming the city and its infrastructure. With high unemployment in the North, the youth who lack opportunities are attracted to Boko Haram because Boko Haram pays its volunteers and gives its members a feeling of belonging, adventure and power.

The tension between Fulani herdsmen and farming communities has also escalated in recent times to include attacks, kidnappings and killings by the nomads. Statistics reveals that between 2007 and 2015, the human carnage perpetrated by the Fulani nomads in different parts of the country has risen to 1012 (Olu-Adeyemi, 2017). The hardest hit areas are Benue, Nassarawa, Taraba, Plateau, Kastina, Kaduna, and Enugu with various pockets of attacks across some of the southern states in Nigeria. While in the past, these Fulani herdsmen do unleash terror on the host communities with knives, bows and arrows, now they operate with sophisticated arms such as riffles and AK-47, attacking at midnig- 
ht, on Sundays, killing indiscriminately, burning houses and looting properties. The magnitude of damages to life and properties, the brutality and impunity are far higher and much deadlier in recent times.

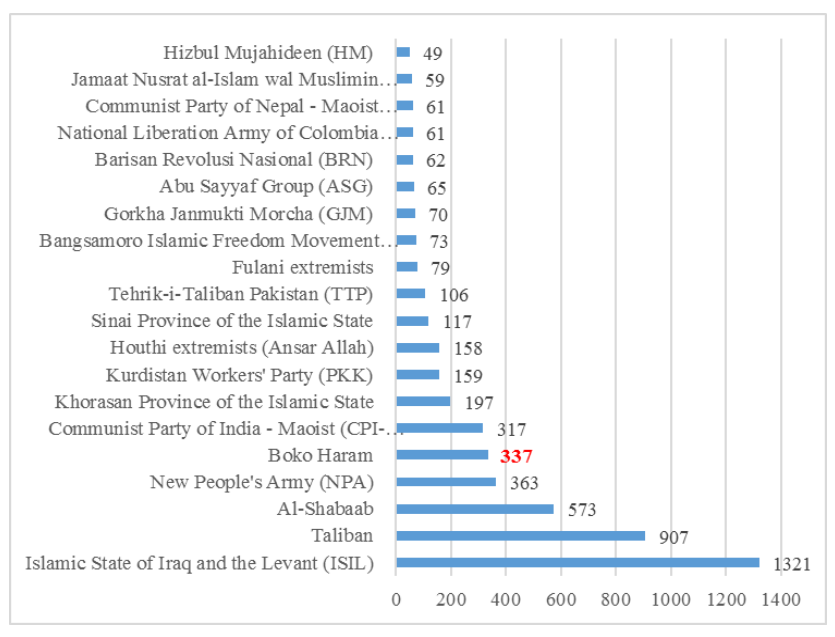

Source: Global Terrorism Database (2017)

Figure 1. Number of Attacks by the Twenty Most Active Perpetrator Groups (2017)

Literature on causes of violence in Nigeria identify many factors like corruption, injustice, hunger, poverty and despondency in the midst of plenty cornered and monopolized by the leaders who use instruments of coercion to suppress the masses in their agitations (Hendrix, 2016; Okoli and Nachanaa, 2016; Oladipo 2013; Olu-Adeyemi, 2017). Many experts have argued that violent extremism in Nigeria today is a consequence of decades of pervasive corruption and neglect of governance. For example, Osagie, Fred and Samuel (2010) showed that deprivation of the indigenes of the dividends of oil proceeds was the greatest cause of conflict of the Niger Delta. Nigeria is the wealthiest country in Africa as reflected by its gross domestic product (GDP). However, its income distribution is highly skewed, meaning the vast majority is in poverty. Nigeria is also poorly governed. For example, Hendrix (2016, p. 4) described the situation in the North thus:

"For years, the central government ignored the humble northeast... For much of the past six years, there have been large parts of Nigeria's northeast where there has been no functional government. For decades, corruption and neglect meant that the region received little in terms of education, healthcare, infrastructure, electricity or other public services. Given its size, it might be logical to assume that Nigeria had state capacity similar to Indonesia, Russia or Brazil. But across Nigeria, public institutions have been hollowed out, with corrupt politicians taking 


\section{Evans \& Kelikume}

away the spoils and neglecting the rot until the country got to this crisis".

It is noteworthy that existing studies have suggested that violence in Nigeria may be a consequence of economic and political factors such as poverty, unemployment, inequality, corruption and poor governance (e.g., Olawale, 2003; Ikelegbe, 2006). Moreover, until recently, studies on causes of violence in Nigeria have been largely conceptual while Niger Delta militancy, Boko Haram terrorism and herdsmen attacks have remained far under-researched (e.g., Evans and Kelikume, 2018; Hendrix, 2016; Okoli and Nachanaa, 2016; Oladipo 2013; Olu-Adeyemi, 2017). This shortage of rigorous empirical research may be attributed as the main cause of inadequate policy guidance on how to stop Niger Delta militancy, Boko Haram terrorism and herdsmen attacks. This study thus fills the gap by examining the effects of impact of poverty, unemployment, inequality, corruption and poor governance on Niger Delta militancy, Boko Haram terrorism and herdsmen attacks. Frustration and aggression theory, expectancy theory and reactance theory, each focusing on different aspects of deprivation, provide the hypothesis that violence is likely to follow deprivation, and therefore, provide the theoretical support for this study. This enquiry is key to any effort to stop Niger Delta militancy, Boko Haram terrorism and Fulani herdsmen attacks in Nigeria.

The rest of the paper is organized as follows. Section 2 presents an overview of the theory and the review of literature. Section 3 describes the data and methodology. Section 4 presents the empirical analysis. Section 5 completes the broader discussion on the impact of poverty, unemployment, inequality, corruption and poor governance on Niger Delta militancy, Boko Haram terrorism and Fulani herdsmen attacks in Nigeria.

\section{LITERATURE REVIEW}

Three theories, each focusing on different aspects of deprivation, provide support to hypothesis that violence is likely to follow deprivation. First, frustration and aggression theory establish that frustration will lead to violence (Hogg, 2016). Second, expectancy theory states that the violation of an expected result leading to deprivation will cause violence (Pornari and Wood, 2010). Third, reactance theory hypothesizes that the removal of behavioral freedom, which leads to the arousal of reactance, may cause violence (Baumeister, Catanese and Wallace, 2002). These three theories highlight the fact that different forms of violence in Nigeria may be a consequence of the different levels of deprivations. What is violence? The word 'violence' is derived from another word 'violate' which means to hurt, break, injure, infringe, desecrate, profane, debauch, defile, outrage, damage, transgress, etc. Simply put, violence is an act of destruction. Violence is the destruction of man's belonging which could range from his dreams, his property, his rights, his moral principles, his life to other things he values and cherishes for his advancement and protection (Ideyi, 2008). 
Brown puts it succinctly $(1987$, p. 7$)$ : "Whatever violates another, in the sense of infringing upon or disregarding or abusing or denying that other, whether physical harm is involved or not, can be understood as an act of violence $\cdots$. In the broadest sense then, an act that depersonalizes would be an act of violence, since $\cdots$ it transforms a person into a thing". In other words, violence involves damage to what the victim holds dear. Oby (2001) emphasized that violence and conflict are unavoidable and keep occurring. "Every day, every individual encounters at least two or three conflicts either at home, at work, at social outings or even when a person sleeps in a bedroom without talking to anyone. Therefore, people are no longer new to those things that cause these conflicts, known as sources of conflicts" (Osagie et al., 2010, p. 83). There are different types of conflicts: conflicts over resources, conflicts over psychological needs and conflicts involving values. In Nigeria, conflicts over resources are more common, as when two or more ethnic groups want the same thing e.g., the Niger Delta oil. In such a case, the parties might attack the resources in the heat of the conflict. Conflicts over psychological needs affect the psyche of the individual and its productive capacity. Bur (2001), Owuamanam (2001), and Onuorah (2001) have provided extensive discussions of conflicts.

Most scholarly works have tended to see the translation into violence as rooted in a negative culture (Olawale, 2003). The source of this culture is regarded variously as urban congestions, environmental stress and superficial religion, new barbarism of crime and violence, the collapse of the educational and social service systems, unemployment and physical hardships, a failing or collapsing state and state institutions and services underlined by neo-patrimonial practices and political failures, and an obsession with violence and violent changes (Ikelegbe, 2006). Olawale (2003) posited that the transformation was a casualty of state weakness and collapse, neo-patrimonialism, the weak and failing public authorities, corruption, abuse and other manifestations of state decay generate armed insurgencies. Resource-rich environments like Nigeria may generate problems and potentials that tend towards violent criminality (Ikelegbe, 2006). The opportunity for quick enrichment, illegal exploitation, and the physical hardships associated with mining are attractions and a conditioning environment for agitation and violence. Configuration of costs and benefits along with the resultant pursuits of grievances may generate resource conflicts and resource-based armed insurgencies and wars (Collier, 2000; Ikelegbe, 2006).

Various studies have analyzed the deep economic problems faced by Nigeria (e.g., Adeniji, Obi and Evans, 2018; Evans, 2019b), especially in relation to violence (e.g., Ikelegbe, 2006). Ikelegbe (2006) analyzed youth militancy and militias in the context of deep economic and resource crises in Nigeria and found that multinational oil company strategies and state repression conduced the emergence and consolidation of the militia phenomenon from the youth who are plagued by unemployment and poverty. The author also found that infiltration of political elites, loss of focus and poor control have combined to turn the militias into perpetrators of crime, violence and insecurity and agents of private 


\section{Evans \& Kelikume}

interests and greed. Ukiwo (2007) explained insurgency in the Niger Delta in the context of the "greed" of militant groups, and argued that insurgency can best be explained by examining the social origins of militant groups. Focusing on the case of the ljaw of Warri, from among whom the Movement for the Emancipation of the Niger Delta (MEND) emerged, Ukiwo (2007) demonstrated that insurgency is the consequence of longstanding experiences of political and social-cultural marginalization.

Okoli and Nachanaa (2016) explored the relationship between militancy and prevalence of petrocriminality in the Niger Delta. The authors posited that the phenomenon of militancy in the Niger Delta has degenerated into a morass of allied criminality in line with the dialectics of petro-rentierism in Nigeria. In analysis of the oil wars and massive oil theft in the Niger delta in the first decade after the transition to civilian-electoral rule in 1999, Schultze-Kraft (2017) showed that organized violence is not exogenous to political settlements; and their (re)production does not always destabilize them; and organized criminal activities associated with the generation of natural resource rents, such as huge theft of crude oil, can contribute to violence mitigation and the stabilization of a contested political settlement.

A few studies have looked at the determinants of welfare (e.g., Evans and Lawanson, 2017; Evans, 2018b), especially in relation to violence (e.g., Evans and Kelikume, 2018). For example, Evans and Kelikume (2018) examined the effects of FDI, trade, aid, remittances and tourism on welfare under terrorism and militancy using ARDL bounds testing approach and the Cobb-Douglas production function for the case of Nigeria for the period 1980 to 2016. The empirical findings showed that, in the short-run, FDI, trade, aid, remittances and tourism have positive significant effects on welfare, even under terrorism and militancy. However, in the long-run, only aid and remittances have significant effects, while FDI, trade and tourism are insignificant. In other words, FDI, trade and tourist inflows are repressed as a result of the presence of terrorism and militancy in the long-run, meaning that they could not thrive in tensed and insecure environments. Their findings also showed that terrorism and militancy have significant negative effects on welfare both in the short- and long-run.

Other studies have looked at government policies (e.g., Evans, 2016; Nwaogwugwu and Evans, 2016; Evans, 2019a), particularly in relation to violence (e.g., Sampson, 2016). For example, Sampson (2016) examined the strategic and operational responses adopted by the Nigerian government in countering Boko Haram terrorism. The author argued that the predominantly military approach to countering Boko Haram terrorism could continue to create tensions between the government and the populace, unless a more robust counter-terrorism strategy is implemented together with major governance and political reforms, aimed at reversing the historic, social and economic imbalance in northern Nigeria. Solomon (2018) argued that counter-terrorism policy has been informed by traditional approaches which are state-centric and militaristic. The author provided an impressive exposition of the historical context to problematize the state, giving an account of how 
structural factors are a significant driver of terrorism.

Ikezue and Ezeah (2017) investigated the causes and effects of pastoral herdsmen grazing conflicts within farming communities in Nigeria. Using the relative deprivation theory, the authors showed that the inability of the Nigerian state to equitably distribute and allocate resources for cattle routes and grazing is at the core of the conflict. Dimelu, Salifu and lgbokwe (2016) examined the causes of conflict in agrarian communities of Kogi in Nigeria. Using a sample of 135 crop famers and 72 herdsmen, the authors showed that effective management of conflicts was constrained by inadequate funding and lack of institutional support by government. Olu-Adeyemi (2017) examined the activities of the Fulani Herdsmen against the background of their persistent violent attacks on farms, farmers and communities across Nigeria. Applying the theory of deprivation, frustration and aggression, the author situated the Fulani herdsmen attacks as the nexus of the deprivations emanating from the plethora of economic, social, environmental and political situations in Nigeria.

Summarily, the existing studies have suggested that violence in Nigeria in the form of Niger Delta militancy, Boko Haram terrorism and herdsmen attacks may be considered as a consequence of economic and political factors such as poverty, unemployment, inequality, corruption and poor governance (e.g., Olawale, 2003; Ikelegbe, 2006). However, until recently, studies on violence in Nigeria have been largely conceptual, while Niger Delta militancy, Boko Haram terrorism and herdsmen attacks have remained far under-researched (e.g., Evans and Kelikume, 2018; Hendrix, 2016; Oladipo 2013; Okoli and Nachanaa, 2016; Olu-Adeyemi, 2017). This shortage of rigorous empirical research may be attributed as the main cause of inadequate policy guidance on how to stop Niger Delta militancy, Boko Haram terrorism and herdsmen attacks. This study thus fills the gap.

\section{-Study Framework}

In many developing countries such as Nigeria, the peculiar material conditions are poor; governance and the economy are problematic; inept and corrupt administrations and poor leadership pervade the political process; poverty, inflation, massive job losses, unemployment, decadent services and infrastructures persist; democracy which is touted as the antidote to these circumstances is smitten with corruption, misrule, violence, and persisting decline (Kelikume and Evans, 2015). The multifarious deprivations lead to mass disillusionment, anger, disorientations and public distrust. It further manifests in the tending of the populace towards shattering, resisting and undermining the ethos and the social fabric of society. The emerging orientation can become increasingly more assertive, activist, rebellious, aggressive and violent. This is indicated in the phenomenon of militia groupings, vigilantes, private armies, armed groups, gangsters and secret cults.

According to Ikelegbe (2006), the multifarious deprivations (e.g., poverty, inequality, unemployment, corruption and poor governance) cause anger, frustration and bitterness as well as 


\section{Evans \& Kelikume}

negative orientations. This can constitute a large pool of disgruntled people amenable to all sorts of political, cultural and other manipulations which easily transform their bitterness and frustration into violence (see Figure 2). Thus, the violence in Nigeria can be said to be as a result of the prevailing unpleasant socio-material conditions pertaining to issues relating to survival, economic deprivation, structural inequities, environmental degradation, governance deficits and political marginalization (Okoli and Nachanaa, 2016). Without a doubt, the citizens feel excluded, marginalized, victimized, abused, and frustrated.

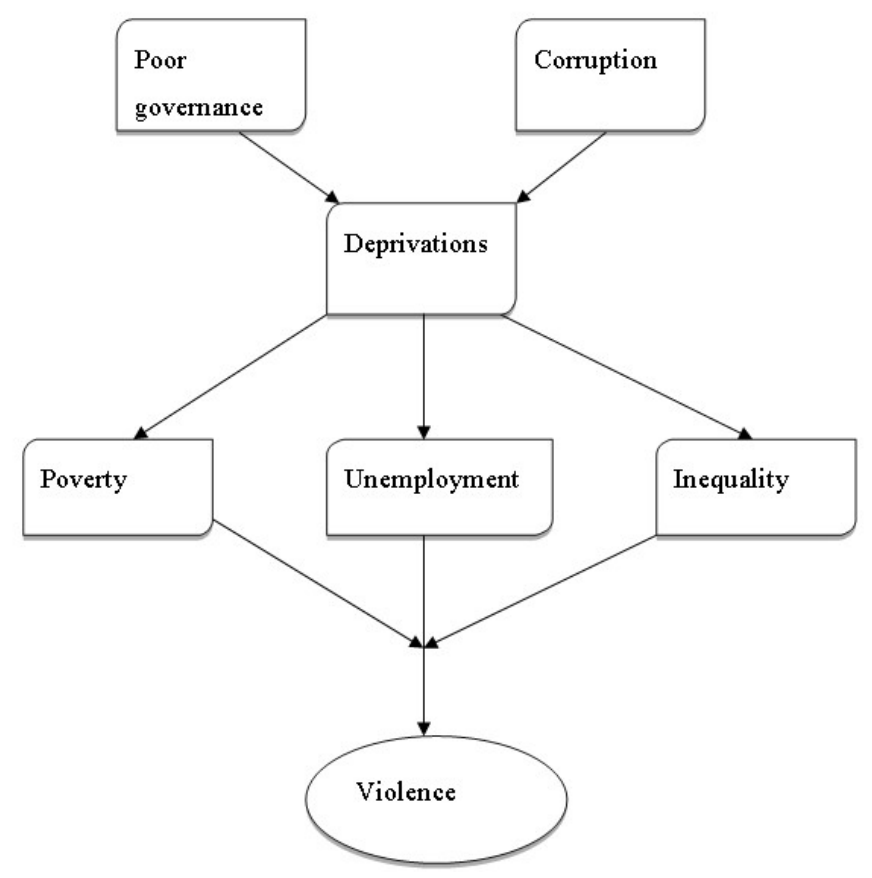

Source: Author's own

Figure 2. Poor Governance, Corruption, Deprivations and Violence

The prevalence of socio-economic insecurity can make the issue of survival critical. The struggle for survival, therefore, is the reason for the series of violence, including the constant, oil theft/bunkering, piracy, and kidnapping in the Niger Delta, asymmetrical bombings and attacks across the northern half of the country by Boko Harram, and the attacks, kidnappings and killings by herdsmen (Evans and Kelikume, 2018; Hendrix, 2016; Okoli and Nachanaa, 2016; Oladipo 2013; Olu-Adeyemi, 2017). As observed by Asuni (2009), the enabling environment for violence in Nigeria includes high levels of unemployed youth, ineffective and corrupt leaders, unemployment, poverty, corruption, and governance failure. Poor, unemployed, uneducated and mis-governed people are frustrated and angry (Adeola, Boso and Evans, 2017; Evans, 2018c). They take to wanton destruction 
as an avenue to vent their frustration against the government (Okoli and Nachanaa, 2016).

\section{METHODOLOGY}

-Data

This study employed annual data over the period 1980-2017 for Nigeria. The data were collected from the World Development Indicators made available by the World Bank (2017), except the data on terrorism which was collected from Global Terrorism Database (2017). Data on transport and communication as a share of GDP were sourced from CBN statistical bulletin (CBN, 2017). Also, the data on corruption was sourced from Transparency International (2017). Nigeria was selected for this study because of the heated issues of terrorism, militancy and herdsmen attacks that plagued the country.

\section{-Model}

The frustration and aggression theory, expectancy theory and reactance theory provide the hypothesis that deprivation is likely to cause violence. Violence in Nigeria in the form of Niger Delta militancy, Boko Haram terrorism and herdsmen attacks may be as a consequence of economic and political factors such as poverty, unemployment, inequality, corruption and poor governance. Therefore, violence is a function of deprivation. According to Ikelegbe (2006), and Okoli and Nachanaa (2016), the violence in Nigeria is a result of the prevailing unpleasant socio-material conditions pertaining to issues relating to survival, economic deprivation, structural inequities, environmental degradation and governance deficits.

Also, econometric studies have shown that the omission of relevant variables in a regression model may lead to bias (Gujarati 2003), the magnitude of which depends on the interaction between the omitted variable, the other explanatory variables and the dependent variable. In order to preclude the omitted variable bias, the model used in this study follows the literature. Also, there are dimensions such as foreign aids to aid the fight against terrorism in the North. These are all included in the present model. Infrastructural variable (i.e., transport, communication and utilities as a share of GDP) is also included in line with Adeola, Evans and Hinson (2018).

Thus, the models for this study are specified in line with the literature and the objectives of the study as follows:

$$
\begin{aligned}
& \text { Nmilita }_{t}=\kappa_{0}+\kappa_{1} \text { Pov }_{t}+\kappa_{2} \text { Ineq }_{t}+\kappa_{3} \text { Ump }_{t}+\kappa_{4} \text { Cor }_{t}+\kappa_{5} \text { Gov }_{t}+\kappa_{6} \text { Infr }_{t}+\kappa_{7} \text { Environ }_{t}+\xi_{t} \\
& \text { Bterr }_{t}=\rho_{0}+\rho_{1} \text { Pov }_{t}+\rho_{2} \text { Ineq }_{t}+\rho_{3} \text { Ump }_{t}+\rho_{4} \text { Cor }_{t}+\rho_{5} \text { Gov }_{t}+\rho_{6} \text { Infr }_{t}+\rho_{7} \text { Aid }_{t}+\varphi_{t} \\
& \text { Htac }_{t}=\eta_{0}+\eta_{1} \text { Pov }_{t}+\eta_{2} \text { Ineq }_{t}+\eta_{3} \text { Ump }_{t}+\eta_{4} \text { Cor }_{t}+\eta_{5} \text { Gov }_{t}+\eta_{6} \text { Infr }_{t}+\zeta_{t}
\end{aligned}
$$




\section{Evans \& Kelikume}

Where, $i=1,2, \cdots, t$, that is, the number of years. Nmilita is Niger Delta militancy (proxied by the number of militant attacks); Bterr is Boko Haram terrorism (proxied by the number of terrorist attacks); Htac is herdsmen attacks (proxied by the number of herdsmen attacks); Pov is poverty (proxied by poverty headcount ratio); Ineq is inequality (proxied by Gini coefficient); Ump is unemployment rate; Cor is corruption; Gov is governance (proxied by general government final consumption expenditure [\% of GDP]); Environ is environmental degradation (proxied by carbon emissions [metric tons per capita]); Infr is infrastructure (proxied by transport and communication [\% of GDP]); and Aid is foreign aid (official development assistance [\% of GDP]). The proxies for the variables are in accord with studies such as Abbas, Masood and Sakhawat (2017), Asongu and Nwachukwu (2018), Chaudhry et al. (2018), Evans (2018a), and Okafor and Piesse (2018).

\section{-Estimation Technique}

The first step of the analysis was to determine the unit root properties of the variables. If all the variables are integrated of $\mathrm{I}(0)$ and $\mathrm{I}(1)$ order, the next step was to test data for cointegration (Evans, 2015). If the variables are shown to be cointegrated, then Pedroni's (2000 and 2001) fully modified OLS method of estimation (FMOLS) estimator is used. FMOLS is a non-parametric approach in which an initial estimation calculates the serial correlation and endogeneity correction terms. The approach produces asymptotically unbiased normally distributed estimates of the long-run elasticities. Extensive discussion of the FMOLS approach can be gleaned from Phillips and Hansen (1990), and Pedroni (2000, 2001).

\section{RESULTS}

Considerable evidence abides in the literature that time series data are often non-stationary, a property which, if ignored in estimation, may lead to spurious regression (Adeola, Boso and Evans, 2017; Chatfield, 2016; Evans, 2017; Nelson and Plosser, 1982). This study uses the Elliot, Rothenberg and Stock Point Optimal unit root test (ERS), which is more computationally robust than the traditional unit root tests (e.g., Augmented Dickey-Fuller,1979; Phillips-Perron, 1988). Table 1 (see Appendix-I) summarizes the results of the ERS test. The results show that some variables are stationary at $I(0)$ and some at $I(1)$, meaning that the variables are a mix of $I(0)$ and $I(1)$ and appropriate for the FMOLS approach.

To apply the FMOLS approach for estimation, a cointegrating relation must first be established among the variables. Therefore, the Hansen Parameter Instability cointegration test is employed to test for cointegrating relationships. Table 2 (see Appendix-II) summarizes the results of the cointegration test. For the three models, the null hypothesis of no cointegration is rejected at the 5 percent level of significance. This suggest the existence of long-run relationships among the variables in the models. 
International Journal of Management, Economics and Social Sciences

Having established the existence of long-run relationships among the variables, the estimation of the models using FMOLS was implemented. In all cases, two outcomes of the FMOLS regression were provided. This allows checking for the robustness of the findings to alternative specifications. First, model (1) was estimated (see Table 3, Appendix-III). Most of the explanatory variables were significant and with the expected signs. For the two estimations, the results show that poverty is a significant cause of Boko Haram terrorism in Nigeria, meaning that increased terrorism is caused by poverty. As well, inequality and unemployment are positively related to terrorism, meaning the higher the levels of inequality and unemployment in the country, the higher the level of terrorism. Corruption also has significant positive effect on terrorism, meaning the higher the levels of corruption, the higher the level of terrorism.

Table 4 (see Appendix-IV) shows the results of estimation of model 2. Most of the explanatory variables are significant and with the expected signs. For the two estimations, the results show that poverty is a significant cause of Niger Delta militancy in Nigeria, meaning that increased militancy is caused by poverty. As well, inequality and unemployment are positively related to militancy, with the statistically significant degree of responsiveness to inequality. Also, results for environmental degradation is significant, meaning that environmental degradation is a significant cause of militancy in the Niger Delta. Corruption also has significant positive effects on militancy, meaning the higher the level of corruption, the higher the level of militancy.

Table 5 (see Appendix-V) shows the results of estimation of model 3. For the two estimations, the results show that poverty is a significant cause of herdsmen attacks in Nigeria, meaning that increased herdsmen attacks is caused by poverty. Inequality and unemployment are positively related to herdsmen attacks and are statistically significant, meaning the higher the levels of inequality and unemployment, the higher the level of herdsmen attacks. Corruption also has significant positive effects on herdsmen attacks, meaning the higher the level of corruption, the higher the level of herdsmen attacks.

\section{DISCUSSION}

The results of this study show that poverty is a significant cause of Boko Haram terrorism in Nigeria, meaning that increased terrorism is caused by poverty. As well, inequality is positively related to terrorism, with the degree of responsiveness to inequality elastic and statistically significant. Thus, inequality is consistent with higher levels of terrorism. Unemployment is also positively related to terrorism, meaning the higher the level of unemployment in the country, the higher the level of terrorism. Corruption also has significant positive effects on terrorism, meaning the higher the levels of corruption, the higher the level of terrorism. These findings are in line with, one, the frustration and 


\section{Evans \& Kelikume}

aggression theory which predicts that frustration will lead to violence (Hogg, 2016); two, the expectancy theory which predicts that the violation of an expected result leading to deprivation will cause violence (Pornari and Wood, 2010); and three, the reactance theory which hypothesizes that the removal of behavioral freedom, which leads to the arousal of reactance, may cause violence (Baumeister, Catanese and Wallace, 2002). These findings are also in line with the literature on causes of violence (e.g., Evans and Kelikume, 2018; Hendrix, 2016; Okoli and Nachanaa, 2016; Oladipo 2013; Olu-Adeyemi, 2017) which has identified causes of violence in Nigeria as corruption, injustice, hunger, poverty and despondency in the midst of plenty cornered and monopolized by the leaders who use instruments of coercion to suppress the masses in their agitations.

Also, the study shows that governance is positive but insignificant, meaning that governance has no significant impact on terrorism; even worse the poor level of governance contributes more to the scourge. Infrastructure is negative but not significant, meaning the more infrastructural provisions in the country, the less terrorism. Infrastructural provisions have preventive effects on terrorism, though insignificant. Also, foreign aid is negative but not significant, meaning the more foreign aid in the country, the less terrorism. Foreign aid has curative effects on terrorism, though insignificant. It is understandable that developing nations such as Nigeria are more vulnerable to terrorism because they are unlikely to have the resources to adequately fight terrorism and may have to depend on foreign aid. This problem is further compounded by corruption, poor governance, and lack of proper judicial systems or rule of law. Such institutional shortcomings breed discontent, which in turn can spur terrorism (Bandyopadhyay, Sandler and Younas, 2013).

Further, the results show that poverty is a significant cause of the Niger Delta militancy in Nigeria, meaning that increased militancy is caused by poverty. As well, inequality is positively related to militancy, with the degree of responsiveness to inequality is statistically significant. Unemployment is also positively related to militancy, meaning the higher the level of unemployment, the higher the level of militancy. Also, environmental degradation is significant, meaning that environmental degradation is a significant cause of militancy in the Niger Delta. Corruption also has significant positive effects on

militancy, meaning the higher the level of corruption, the higher the level of militancy. These findings can be explained by the fact that resource-rich environments like Nigeria can generate problems and potentials that tend towards violent criminality (Ikelegbe, 2006). The opportunity for quick enrichment, illegal exploitation, and the physical hardships associated with mining are a conditioning environment for militancy. The permutations of costs and benefits in conjunction with the resultant pursuits of grievances can generate resource conflicts and resource-based armed insurgencies and wars (Collier, 2000; Ikelegbe, 2006). These findings are in line with Ikelegbe (2006) who showed that multinational oil company strategies and state repression conduced the emergence and consolidation of the militia phenomenon from the youth who are plagued by unemployment and poverty. Ukiwo (2007) showed 
that insurgency is the consequence of longstanding experiences of political and social-cultural marginalization. Evans and Kelikume (2018) also showed that terrorism and militancy have significant negative effects on welfare both in the short- and long-run.

The results also show that governance has negative but insignificant effect, meaning that governance has corrective effects on militancy and that the government is sensitive to events and trends in the Niger Delta. The effect is not significant though. Infrastructure is negative but not significant, meaning the more infrastructural provisions in the country, the less militancy. Infrastructural provisions have salutary effects on militancy, though insignificant. These findings are in line with Ikelegbe (2006) who showed that infiltration of political elites, loss of focus and poor control have combined to turn militias into perpetrators of crime, violence and insecurity. These are related to unemployment and physical hardships, a failing state underlined by neo-patrimonial practices and political failures (Ikelegbe, 2006). Olawale (2003) posited that the circumstances were a casualty of state weakness and collapse, neo-patrimonialism, weak and failing public authorities, corruption, and abuse.

The results also show that poverty is a significant cause of herdsmen attacks in Nigeria, meaning that increased herdsmen attacks is caused by poverty. Inequality is positively related to herdsmen attacks and is statistically significant. Unemployment is also positively related to herdsmen attacks, meaning the higher the level of unemployment, the higher the level of herdsmen attacks. Corruption also has significant positive effects on herdsmen attacks, meaning the higher the levels of corruption, the higher the level of herdsmen attacks. These findings are in line with Olu-Adeyemi (2017) who situated the Fulani herdsmen attacks as the nexus of the deprivations emanating from the plethora of economic, social, environmental and political situations in Nigeria. Ikezue and Ezeah (2017) showed that the inability of the Nigerian state to equitably distribute and allocate resources for cattle routes and grazing is at the core of the herdsmen conflict. The migration of herdsmen from the far North towards the central part of Nigeria has resulted in a sort of dialectical relations between the Fulani herdsmen and the settled native farmers, which has been complicated by "the rising incidence of livelihood insecurity among the farming and herding communities as a result of the dwindling ecological fortunes of the region. This scenario has led to desperate, violent struggles for access to and control of scarce ecological space and resources, a situation that has engendered dire humanitarian, social, socioeconomic and economic consequences. The fierce and often virulent nature of this struggle have found expression in a vicious circle of violence and mutual vendetta" (Okoli and Atelhe, 2014, p. 76). The regression results demonstrate, as well, that governance is negative, but insignificant, meaning that governance have counteractive effect on herdsmen attacks. The effect is not significant though. Infrastructure is negative but not significant, meaning the more infrastructural provisions in the country, the less herdsmen attacks. Infrastructural provisions have counteractive effects on herdsmen attacks, 


\section{Evans \& Kelikume}

though insignificant. The attempt by the settled native farmers to displace or marginalize the herdsmen in their common ecological domain has led to a vicious circle of vendetta. The rising wave of attacks among the Fulani herdsmen in Nigeria is therefore driven by a do-or-die struggle for survival in an environment that is hostile to their collective sustainable livelihood. These findings are in line with Oarhe and Oyibo (2010) which showed that successive governments in Nigeria largely exemplify "the phenomenon of bad governance, which manifests in chronic poverty, massive unemployment, pervasive corruption, policy performance failure and infrastructure decay that engenders frustration, disillusionment and psycho-moral dislocation that create the enabling environment for the eruption of various forms of violent conflicts" (p. 1). Violence and the threat of violence holds back the economy, limiting mobility, and access to economic opportunities. Violence confines the success of infrastructure programs meant for improving access to resources and services (e.g., education, health, jobs). No water at the standpipe, bus services that don't run, and street lights with no power all serve to increase risks.

\section{CONCLUSION}

This study has examined the impact of poverty, unemployment, inequality, corruption and poor governance on Niger Delta militancy, Boko Haram terrorism and herdsmen attacks in Nigeria using FMOLS and annual data over the period 1980-2017. The outcomes of the estimations have shown that poverty, unemployment, inequality, corruption and poor governance are significant causes of Niger Delta militancy, Boko Haram terrorism and herdsmen attacks in Nigeria. In line with theories of deprivation, the study found that the various deprivations in the country have led to violence and aggression in the form of Niger Delta militancy, Boko Haram terrorism and herdsmen attacks.

\section{IMPLICATIONS}

The findings of this study have shown that the causes of violence in Nigeria are the deprivations, unemployment and physical hardships, a failing or collapsing state and state institutions and services underlined by neo-patrimonial practices and political failures. These are the consequences of the nexus of the deprivations emanating from the plethora of economic, social, environmental and political situations (e.g., poverty, inequality, unemployment, corruption and poor governance) in Nigeria. The translation into violence is rooted in the deprivations which have led to mass disillusionment, anger, disorientations and public distrust, further manifesting in the populace towards shattering and undermining the social fabric of society in the form of rebellion, aggression and violence.

In line with theories of violence, the exclusion, marginalization and frustration from the multifarious deprivations (e.g., poverty, inequality, unemployment, corruption and poor governance) have caused 
anger, frustration and bitterness as well as constituted a large pool of disgruntled people amenable to violence. Thus, violence emerges as a result of the prevailing unpleasant socio-material conditions pertaining to survival, economic deprivation, structural inequities, environmental degradation and governance deficits. Resource-rich environments like Nigeria may easily generate problems and potentials that tend towards violence. The high levels of poverty, inequality, unemployment, corruption and poor governance coupled with opportunity for quick enrichment are a conditioning environment for agitation and violence. The resultant pursuits of grievances may generate resource conflicts and violence.

The Nigerian government needs to make tangible and measurable progress against the oil theft/bunkering, piracy and kidnapping in the Niger Delta, asymmetrical bombings and attacks across the northern half of the country by Boko Harram, and the attacks, kidnappings and killings by herdsmen. The long-term solution to the conflicts and violence is to remove their causes. The government must tackle the enablers of violence in Nigeria which includes high levels of unemployed youth, ineffective and corrupt leaders, unemployment, poverty, corruption, and governance failure. Poor, unemployed, uneducated and mis-governed people are frustrated and angry. They take to wanton destruction as an avenue to vent their frustration against the government.

Governance must therefore work to the benefit of its own citizens. Poverty and inequality should be eliminated if Nigeria is to be spared of violence. The government should create job opportunities for its unemployed youth. Without opportunity to work the people would feel that the society is against them and will wage war against them. Provision of employment has to be Nigerian priority. When the people are educated and fully employed, when they feel a sense of belongingness to the broader economy, then the allure of Boko Haram, militancy and violence will come to its end.

Deprivations such as the inability of the Nigerian state to equitably distribute and allocate resources for cattle routes and grazing deserves immediate and strategic attention. Even the effective management of attacks and conflicts are always constrained by inadequate funding and lack of institutional supports by government. The government must tackle the peculiar poor material conditions, the problematic governance and economy, inept and corrupt administrations and poor leadership in the political process. Poverty, inflation, unemployment, massive job losses, decadent services and infrastructures persist be tackled head on. Corruption, misrule and violence must be avoided in governance. Politics should be ridden of an avenue-to-amass-wealth syndrome. Governance is a call for selfless service, a call to think out ideas, make policies and implement the same with a view to building a nation state whose citizens will meet their basic needs such as food, shelter, clothing, education, health, security and other human needs.

\section{LIMITATIONS AND FUTURE DIRECTIONS}




\section{Evans \& Kelikume}

While this study has provided fruitful initial insights into the effects of poverty, unemployment, inequality, corruption and poor governance on violence from a developing country perspective, the limitations of the study should however be noted. The fact that the study is limited to Nigeria suggests that the findings should be generalized cautiously, though it is likely to have relevance and applicability to other developing countries. Further research can therefore seek to shed light on the multifaceted nature of the effects of poverty, unemployment, inequality, corruption and poor governance on violence in different contexts. Further, studies of this nature are always subject to the possibility that few unmeasured confounding variables explain the observed effects. Future studies could extend the findings of this study by incorporating more variables that can perhaps influence the observed effects. More sophisticated econometric tests would also allow more insights into how the presence of these variables could influence the results and the related interpretations.

\section{REFERENCES}

Abbas, F., Masood, A. \& Sakhawat, A. (2017). What determine remittances to Pakistan? The role of macroeconomic, political and financial factors. Journal of Policy Modeling, 39(3): 519-531.

Adeniji, S. O., Obi, B. \& Evans, O. (2018). The impact of oil price shocks on stock market prices volatility in Nigeria. Journal of Global Economy, 14(3): 173-190.

Adeola, O., Boso, N., \& Evans, O. (2017). Drivers of international tourism demand in Africa. Business Economics, 53(1): 2536.

Adeola, O., Evans, O. \& Hinson R. E. (2018). Tourism and economic wellbeing in Africa. In Positive Tourism in Africa. Routledge: Taylor \& Francis.

Asongu, S. \& Nwachukwu, J. (2018). Fighting terrorism: Empirics on policy harmonization. German Economic Review, 19(3): 237-259.

Asuni, J. B. (2009). Blood oil in the Niger Delta. Official Report of the United States Institute of Peace, Washington, DC.

Bandyopadhyay, S., Sandler, T. \& Younas, J. (2013). Foreign direct investment, aid, and terrorism. Oxford Economic Papers, 66(1): 25-50.

Baumeister, R. F., Catanese, K. R. \& Wallace, H. M. (2002). Conquest by force: A narcissistic reactance theory of rape and sexual coercion. Review of general psychology, 6(1): 92-135.

Bur, A. (2001). The dynamics of conflict resolution and national integration: the Nigerian experience. A paper presented at the 25th Annual Conference of the Counselling Association of Nigeria (CASSON), Makurdi from 20th - 24th August 2001.

Chatfield, C. (2016). The analysis of time series: An introduction. CRC press.

Chaudhry, N., Roubaud, D., Akhter, W. \& Shahbaz, M. (2018). Impact of terrorism on stock markets: empirical evidence from the SAARC region. Finance Research Letters. DOI: 10.1016/j.frl.2018.02.024.

Chuku, C., Ima-Abasi, I. \& Dominic, A. (2017). Working paper 284-growth and fiscal consequences of terrorism in Nigeria. African Development Bank.

Dickey, D. A. \& Fuller, W. A. (1979). Distribution of the estimators for autoregressive time series with a unit root. Journal of the American Statistical Association, 74(366): 427-431.

Dimelu, M. U., Salifu, E. D. \& Igbokwe, E. M. (2016). Resource use conflict in agrarian communities, management and challenges: A case of farmer-herdsmen conflict in Kogi State, Nigeria. Journal of Rural Studies, 46, 147-154.

Evans, O. (2018a). Connecting the poor: The internet, mobile phones and financial inclusion in Africa, Digital Policy, Regulation and Governance, https://doi.org/10.1108/DPRG-04-2018-0018.

Evans, O. (2019a). Digital government: ICT \& public sector management in Africa. In New trends in management: regional, cross-border and global perspectives. London: London Scientific Publishing.

Evans, O. (2018b). Repositioning for increased digital dividends: internet usage and economic wellbeing in sub-Saharan Africa, Journal of Global Information Technology Management. 22(1): 47-70.

Evans O. \& Lawanson O. (2017) A multi-sectoral study of financial inclusion and economic output in Nigeria. "Ovidius" University Annals-Economic Sciences Series, 17(1): 195-204.

Evans, O. (2015). The effects of economic and financial development on financial inclusion in Africa. Review of Economic and Development Studies, 1(1): 17-25

Evans, O. (2016). The effectiveness of monetary policy in Africa: Modeling the impact of financial inclusion. Iranian Economic Review, 20(3): 327-337.

Evans, O. (2018c). Improved financial performance without improved operational efficiency: the case of Nigerian firms. Forum 
Scientiae Oeconomia, 6(3): 25-39.

Evans, O. (2019b) Money, Inflation and output in Nigeria and South Africa: Could Friedman and Schwartz be right. Journal of African Business. 20(3): 392-406

Evans, O. \& Kelikume, I. (2018). The effects of foreign direct investment, trade, aid, remittances and tourism on welfare under terrorism and militancy. International Journal of Management, Economics and Social Sciences, 7(3): 206-232.

Evans, O., Adeniji, S. O., Nwaogwugwu, I., Kelikume, I., Dakare, O. \& Oke O. O. (2018). The relative effect of monetary and fiscal policy on economic development in Africa: A GMM approach to the St. Louis equation. Business and Economic Quarterly, 2, 3-23.

Global Terrorism Database (2017). Global Terrorism Database. Retrieved from https://www.start.umd.edu/gtd/ on 07 October 2018.

Hendrix, S. E. (2016). Combating terrorism and violent extremism in Nigeria: Defining a new approach to winning modern Jihadist conflict. The International Lawyer, 49(3): 427-450.

Hogg, M. A. (2016). Social identity theory. In Understanding peace and conflict through social identity theory (pp. 3-17). Cham: Springer.

Ideyi, N. (2008). The root cause of violence in Nigeria: The Niger Delta crisis, a reference point. OGIR/SI: A New Journal of African Studies, 5(1): 85-109.

Ikelegbe, A. (2006). Beyond the threshold of civil struggle: youth militancy and the militiaization of the resource conflicts in the Niger Delta region of Nigeria. African Study Monographs 27(3): 87-122

Ikezue, C. E. \& Ezeah, P. (2017). Recurrent Conflicts among Migrant Fulani Herdsmen and Indigenous Communities of Southern Nigeria. International Journal of Health and Social Inquiry, 3(1): 152-169.

Kelikume, I. \& Evans, O. (2015). Inflation targeting as a possible monetary framework for Nigeria. Global Conference on Business \& Finance Proceedings, 10(1): 420.

Nelson, C. R. \& Plosser, C. R. (1982). Trends and random walks in macroeconomic time series: some evidence and implications. Journal of monetary economics, 10(2): 139-162.

Nwaogwugwu, I. \& Evans, O. (2016). A sectoral analysis of fiscal and monetary actions in Nigeria. The Journal of Developing Areas, 50(4): 211-230.

Oarhe, O. \& Oyibo, E. (2010). Governance and violent conflicts in Nigeria. Lwati: A Journal of Contemporary Research, 7(1): https://www.ajol.info/index.php/lwati/article/view/61064.

Oby, E. (2001). Counselling for conflict resolution. A paper presented at the 25th Annual Conference of the Counselling Association of Nigeria (CASSON), Makurdi from $20^{\text {th }}-24^{\text {th }}$ August, 2001

Okafor, G. \& Piesse, J. (2018). Empirical investigation into the determinants of terrorism: Evidence from fragile states. Defense and Peace Economics, 29(6): 697-711.

Okoli, A. C. \& Atelhe, G. A. (2014). Nomads against natives: A Political ecology of herder/farmer conflicts in Nasarawa state, Nigeria. American International Journal of Contemporary Research, 4(2): 76-88.

Okoli, A. C. \& Nachanaa, D. A. (2016). Militancy and the dilemma of petro-rentier criminality in the Niger Delta. Online Journal of Arts, Management \& Social Sciences, 1(1): 219-237.

Oladipo, S.B. (2013). Vision 20-20-20 and the menace of vandalism: Xlibris Corporation.

Olawale, I. (2003). Youth, culture, state collapse and nation building in West Africa: The nexus revisited. Paper presented at the Council for the Development Social Science Research in Africa (CODESRIA), West Africa Sub-Regional Conference, 6-7 September. Cotonou, Benin.

Olu-Adeyemi, L. (2017). Deprivation, frustration and aggression: an interrogation of Fulani herdsmen terror in Nigeria. Advances in Social Sciences Research Journal, 4(15): 1-13

Olufemi, B. \& Aganihu, E. (1999). Obasanjo clears military of rape charge, angry over killings. The Guardian, Lagos. Wednesday, November 17

Onuorah, E. (2001). Counselling for peaceful co-existence in marital life. A paper presented at the 25th Annual Conference of the Counselling Association of Nigeria (CASSON), Makurdi from $20^{\text {th }}-24^{\text {th }}$ August 2001.

Osagie, J., Fred, A. \& Samuel, E. (2010). Causes of conflicts in the Niger Delta region of Nigeria as expressed by the youth in Delta State. Procedia-Social and Behavioral Sciences, 5, 82-89.

Owuamanam, T. (2001). Counselling intervention of marital conflicts among Nigerian couples. A paper presented at the 25th Annual Conference of the Counselling Association of Nigeria (CASSON), Makurdi from $20^{\text {th }}-24^{\text {th }}$ August.

Pedroni, P. (2000). Fully Modified OLS for heterogeneous cointegrated panels. Advances in Econometrics, 15, 93-130.

Pedroni, P. (2001). Purchasing power parity tests in cointegrated panels. Review of Economics and Statistics, 83(4): 727-731.

Phillips P C B \& Hansen B E (1990), Statistical inference in instrumental variable regression with I(1) processes, The Review of Economic Studies, 57(1): 99-125.

Phillips, P. C. \& Perron, P. (1988). Testing for a unit root in time series regression. Biometrika, 75(2): 335-346.

Pornari, C. D. \& Wood, J. (2010). Peer and cyber aggression in secondary school students: The role of moral disengagement, hostile attribution bias, and outcome expectancies. Aggressive behavior, 36(2): 81-94.

Sampson, I. T. (2016). The dilemmas of counter-bokoharamism: Debating state responses to Boko Haram terrorism in northern Nigeria. Security Journal, 29(2): 122-146.

Schultze-Kraft, M. (2017). Understanding organized violence and crime in political settlements: oil wars, petro-criminality and amnesty in the Niger Delta. Journal of International Development, 29(5): 613-627.

Solomon, H. (2018). Terrorism and counter terrorism in Africa: Fighting insurgency from Al-Shabaab, Ansar Dine and Boko Haram. African Affairs, 117(466): 163-164.

Transparency International (2017). Global Corruption Report 2007. Cambridge University Press.

Ukiwo, U. (2007). From "pirates" to "militants": A historical perspective on anti-state and anti-oil company mobilization among 


\section{Evans \& Kelikume}

the ljaw of Warri, Western Niger Delta. African Affairs, 106(425): 587-610.

Watts, M.J. (2007). Petro-insurgency or criminal syndicate? Conflict and violence in the Niger Delta. Review of Africa Political Economy, 34(114): 637-660.

World Bank (2017) World Development Indicators, Retrieved from http://databank.worldbank.org/ data/ reports. aspx? Source =world-development-indicators 


\begin{tabular}{ccc}
\hline & $\mathbf{I}(\mathbf{0})$ & $\mathbf{I}(\mathbf{1})$ \\
\hline Pov & 35.71 & $3.57^{* *}$ \\
Ump & 3.74 & $3.41^{* * *}$ \\
Ineq & 7.72 & $2.59^{* *}$ \\
Cor & 17.04 & $1.56^{*}$ \\
Gov & $2.11^{* *}$ & $0.52^{*}$ \\
Infr & 7.54 & $3.19^{* * *}$ \\
Environ & 12.72 & $1.51^{*}$ \\
Aid & 2.13 & 0.53 \\
Bterr & $2.37 * *$ & $1.37^{*}$ \\
Nmilita & $3.10^{* * *}$ & $1.37^{*}$ \\
Htac & $2.61^{* *}$ & $2.45^{* *}$ \\
\hline & $1 \%$ level & 1.87 \\
Test critical values: & $5 \%$ level & 2.97 \\
& $10 \%$ level & 3.91 \\
\hline
\end{tabular}

Note: *significant at $1 \% ;{ }^{* *}$ significant at $5 \% ;{ }^{* * *}$ significant at $10 \%$.

Lag length is selected using Spectral OLS AR based on SIC, maxlag=9.

Table 1. Elliott-Rothenberg-Stock Unit Root Test 
Evans \& Kelikume

Appendix-II

\begin{tabular}{ccc}
\hline Series & LC statistic & Prob. \\
\hline Bterr Pov Ump Ineq Cor Gov Infr Aid & 4.56 & $<0.01$ \\
Nmilita Pov Ump Ineq Cor Gov Infr Environ & 7.57 & $<0.00$ \\
Htac Pov Ump Ineq Cor Gov Infr & 6.11 & $<0.01$ \\
\hline
\end{tabular}

Note: "Hansen $(1992 \mathrm{~b}) \mathrm{Lc}(\mathrm{m} 2=4, \mathrm{k}=0) p$-values, where $\mathrm{m} 2=\mathrm{m}-\mathrm{p} 2$ is the number of stochastic trends in the asymptotic Distribution.

Table 2. Cointegration Test - Hansen Parameter Instability 


\begin{tabular}{ccc}
\hline & $\mathbf{( 1 )}$ & $\mathbf{( 2 )}$ \\
\hline Poverty (Pov) & $0.028^{* *}$ & $0.025^{*}$ \\
Inequality (Ineq) & $0.044^{* *}$ & $0.063^{*}$ \\
Unemployment (Unemp) & $0.392^{* * *}$ & $0.331^{* * *}$ \\
Corruption (Cor) & $0.233^{* * *}$ & $0.230^{* * *}$ \\
Governance (Gov) & 0.002 & 0.012 \\
Infrastructure (Infr) & & -0.017 \\
Foreign Aid (Aid) & & -0.022 \\
R- squared & 0.664 & 0.701 \\
\hline Note: * significant at 1\%; ${ }^{* *}$ significant at 5\%; ${ }^{* * *}$ significant at 10\%. Long-run covariance \\
estimate (Prewhitening with lags = 1 from AIC maxlags = 3, Bartlett kernel, Newey-West \\
fixed bandwidth =4.0000). \\
Dependent Variable: Boko Haram Terrorism.
\end{tabular}

Table 3. The Impact of Poverty, Unemployment, Inequality, Corruption, and Poor Governance on Boko Haram Insurgency 
Evans \& Kelikume

Appendix-IV

\begin{tabular}{ccc}
\hline & (1) & (2) \\
\hline Poverty (Pov) & $0.007^{* *}$ & $0.008^{*}$ \\
Inequality (Ineq) & $0.042^{*}$ & $0.029^{*}$ \\
Unemployment (Unemp) & $0.393^{*}$ & $0.215^{*}$ \\
Corruption (Cor) & $0.555^{*}$ & $0.579^{*}$ \\
Governance (Gov) & -0.020 & -0.014 \\
Infrastructure (Infr) & & -0.014 \\
Environmental degradation & & $0.079^{* *}$ \\
(Environ) & 0.803 & 0.837485 \\
R-squared & &
\end{tabular}

Table 4. The Impact of Poverty, Unemployment, Inequality, Corruption, and Poor Governance on the Niger Delta Militancy 
International Journal of Management, Economics and Social Sciences

Appendix-V

\begin{tabular}{ccc}
\hline & $\mathbf{( 1 )}$ & $\mathbf{( 2 )}$ \\
\hline Poverty (Pov) & $0.015^{* * *}$ & $0.017^{* * *}$ \\
Inequality (Ineq) & $0.039^{*}$ & $0.039^{* *}$ \\
Unemployment (Unemp) & $0.087^{* *}$ & 0.120 \\
Corruption (Cor) & $0.419^{*}$ & $0.440^{*}$ \\
Governance (Gov) & -0.008 & -0.002 \\
Infrastructure (Infr) & & -1.137 \\
R-squared & 0.744 & 0.749 \\
\hline Note: $^{*}$ significant at 1\%; ${ }^{* *}$ significant at 5\%; ${ }^{* * *}$ significant at 10\%. Long-run covariance \\
estimate (Prewhitening with lags = 1 from AIC maxlags = 3, Bartlett kernel, Newey-West fixed \\
bandwidth = 4.0000). \\
Dependent Variable: Fulani Herdsmen's Attacks.
\end{tabular}

Table 5. The Impact of Poverty, Unemployment, Inequality, Corruption, and Poor Governance on Fulani Herdsmen's Attacks 